\title{
Numerical simulation and optimization of CdS/p-Si Heterojunction solar
}

\section{cells}

Chunyan Duan ${ }^{1, \mathrm{a}}$, Yingwen Zhao ${ }^{2, \mathrm{~b}}$, Shenghao $\mathrm{Li}^{2, \mathrm{c}}$, Qun Ban ${ }^{1, \mathrm{~d}}$, Yizhan

Chen $^{3, e}$ Hui Shen $2, f$

${ }^{1}$ Electronic Information Department, Foshan Polytechnic, Foshan 528131, China

${ }^{2}$ Sun Yat-Sen University, Institute for Solar Energy Systems, Guangdong Provincial Key

Laboratory of Photovoltaic Technology, Guangzhou 510006, China

${ }^{3}$ School of Applied Physics and Materials, Wuyi University, Jiangmen 529020, China)

adcylgang@163.com, b364684256@qq.com, ‘460917143@qq.com, d36060895@qq.com, e54397068@qq.com, 'shenhui1956@163.com

Keywords: CdS/Si; heterojunction; solar cell; simulation; AFORS-HET

Abstract. In this paper, numerical simulation was made to analyze and optimize the important factors of CdS/p-Si heterojunction solar cell, which include work function of TCO layers and back surface field (BSF), thickness of $\mathrm{CdS}$ thin film and silicon substrate. The results of simulation indicated that the TCO work function is supposed to be lower than $4.4 \mathrm{eV}$, while the work function of BSF is supposed to be higher than $4.8 \mathrm{eV}$. The improper TCO work function is found to be the cause of the reverse electric field. The improper BSF work function also affects the solar cell performance, but does not cause the reverse electric field. The thickness of the CdS thin films has an important influence on the electrical performance of CdS/p-Si solar cell, the VOC and JSC decrease as the thickness of CdS thin film increases. Undoped CdS/p-Si solar cells were fabricated by thermal evaporation and the PCE of $10.63 \%$ was measured under standard condition after partial structure optimization of CdS/p-Si solar cell (the area of cell is $1 \mathrm{~cm} 2$ ). The difference between the simulation and experiment result is discussed.

\section{Introduction}

Crystalline silicon solar cells have the advantages of high efficiency and mature technology. However, the wafers must go through several high temperature processes during cell fabrication. In addition, thin film solar cells such as a-Si/ $\mu-\mathrm{Si}, \mathrm{CdTe}$, CIGS consume less raw materials and have lower cost, whereas their power conversion efficiency (PCE) is lower than crystalline silicon solar cells. The combination of crystalline silicon solar cells and thin film solar cells has become an interesting research direction to avoid their shortcomings. Heterojunction (HJ) solar cells based on crystalline silicon wafers draw a worldwide attention for the lower temperature processing. Different materials such as CdS [1, 2], ZnS [3], ZnO [4], AZO [5], ITO [6], $\mathrm{WO}_{3}$ [7, 8], $\mathrm{MoO}_{3}$ [9, 10] have been applied as the emitter of HJ solar cells. Among these materials, the PCE of silicon based HJ solar cells exceeded 25\% [11, 12] with doped a-Si:H thin film as the emitter, which demonstrates the potential of HJ solar cells.

$\mathrm{CdS}$ is a widely used window layer material for solar cells $[13,14]$ with an energy band $\left(\mathrm{E}_{\mathrm{g}}\right)$ of $2.42 \mathrm{eV}$. It has better short wavelength transparency than the a-Si:H thin film ( $\mathrm{E}_{\mathrm{g}}$ about $\left.1.7 \mathrm{eV}\right)$. The best efficiency of $\mathrm{CdS} / \mathrm{Si} \mathrm{HJ}$ solar cell reported so far is $11.3 \%$, which was measured under a light 
intensity of $45 \mathrm{~W} / \mathrm{m}^{2}$, and the solar cell area was $0.16 \mathrm{~cm}^{2}$ [2]. The same research group reported later that the $1 \mathrm{~cm}^{2} \mathrm{CdS} / \mathrm{Si}$ solar cell yielded a PCE of $10.6 \%$ under standard test condition of $\mathrm{AM} 1.5,1000 \mathrm{~W} / \mathrm{m}^{2}$ and $25^{\circ} \mathrm{C}$ [1]. However, the simulation analysis of $\mathrm{CdS} / \mathrm{Si} \mathrm{HJ}$ solar cells has not been reported. In this work, we simulate and optimize some structure parameters of CdS/Si HJ solar cells. The PCE of CdS/Si HJ solar cell was improved by the assist of numerical simulation.

\section{Simulation details}

The simulation is performed by AFORS-HET v.2.4 [15], which focuses on HJ solar cell simulation [16]. It is processed under the steady-state calculation model (DC-model) and standard illumination condition of AM1.5, 300K. Work functions of the TCO and the back surface field (BSF) are discussed. The thickness of CdS thin film and silicon substrate are researched. Table 1 gives the main parameters used for the simulation.

Table 1 Main simulation parameters in CdS/Si HJ solar cell

\begin{tabular}{ccc}
\hline parameters & $\mathrm{n}-\mathrm{CdS}$ & $\mathrm{p}-\mathrm{Si}$ \\
\hline Thickness $(\mu \mathrm{m})$ & 0.02 & 200 \\
Dielectric constant & 8.9 & 11.9 \\
Electron affinity $(\mathrm{eV})$ & 4.05 & 4.05 \\
Bandgap $(\mathrm{eV})$ & 2.42 & 1.12 \\
Optical bandgap $(\mathrm{eV})$ & 2.42 & 1.12 \\
Effective conduction band density $\left(\mathrm{cm}^{-3}\right)$ & $1.5 \times 10^{18}$ & $2.8 \times 10^{19}$ \\
Effective valance band density $\left(\mathrm{cm}^{-3}\right)$ & $1.8 \times 10^{19}$ & $2.7 \times 10^{19}$ \\
Electron mobility $\left.\left(\mathrm{cm}^{2} \cdot \mathrm{Vs}\right)^{-1}\right)$ & 50 & 1041 \\
Hole mobility $\left(\mathrm{cm}^{2} \cdot \mathrm{Vs}^{-1}\right)$ & 20 & 412.9 \\
Doping concentration acceptors $\left(\mathrm{cm}^{-3}\right)$ & 0 & $1.5 \times 10^{16}$ \\
Doping concentration donators $\left(\mathrm{cm}^{-3}\right)$ & $6 \times 10^{18}$ & 0 \\
Electron thermal velocity $\left(\mathrm{cm}^{-3} \mathrm{~s}^{-1}\right)$ & $1 \times 10^{7}$ & $1 \times 10^{7}$ \\
Hole thermal velocity $\left(\mathrm{cm}^{-1} \mathrm{~s}^{-1}\right)$ & $1 \times 10^{7}$ & $1 \times 10^{7}$ \\
Layer density $\left(\mathrm{g} \cdot \mathrm{cm}^{-3}\right)$ & 4.826 & 2.328 \\
Auger electron recombination coefficient $\left(\mathrm{cm}^{6} \cdot \mathrm{s}^{-1}\right)$ & 0 & $2.2 \times 10^{-31}$ \\
Auger hole recombination coefficient $\left(\mathrm{cm}^{6} \cdot \mathrm{s}^{-1}\right)$ & 0 & $9.9 \times 10^{-32}$ \\
Band to band recombination coefficient $\left(\mathrm{cm}^{3} \cdot \mathrm{s}^{-1}\right)$ & 0 & 0 \\
\hline
\end{tabular}

\section{Results and discussions}

Work function of TCO layer in HJ solar cells is known to be crucial for the performance of solar cells. The influence of work function of TCO layer on $\mathrm{CdS} / \mathrm{Si}$ solar cells was evaluated. The variation of open-circuit voltage $\left(\mathrm{V}_{\mathrm{OC}}\right)$, short-circuit current density $\left(\mathrm{J}_{\mathrm{SC}}\right)$, fill factor $(\mathrm{FF})$ and PCE as the function of work function of TCO layer for CdS/Si solar cells is depicted in Fig.1. The dash red line means the flat band condition when the TCO layer has the same work function as CdS layer. The results show that all the parameters of the CdS/Si solar cell decrease with the work function of TCO increasing. $\mathrm{J}_{\mathrm{SC}}$ decreases gradually as the work function increases. $\mathrm{V}_{\mathrm{OC}}$ and FF drop dramatically when the value of work function exceeds $4.4 \mathrm{eV}$. As a result, PCE of the CdS/Si solar cells is highly affected when the work function of TCO layer is higher than $4.4 \mathrm{eV}$. 

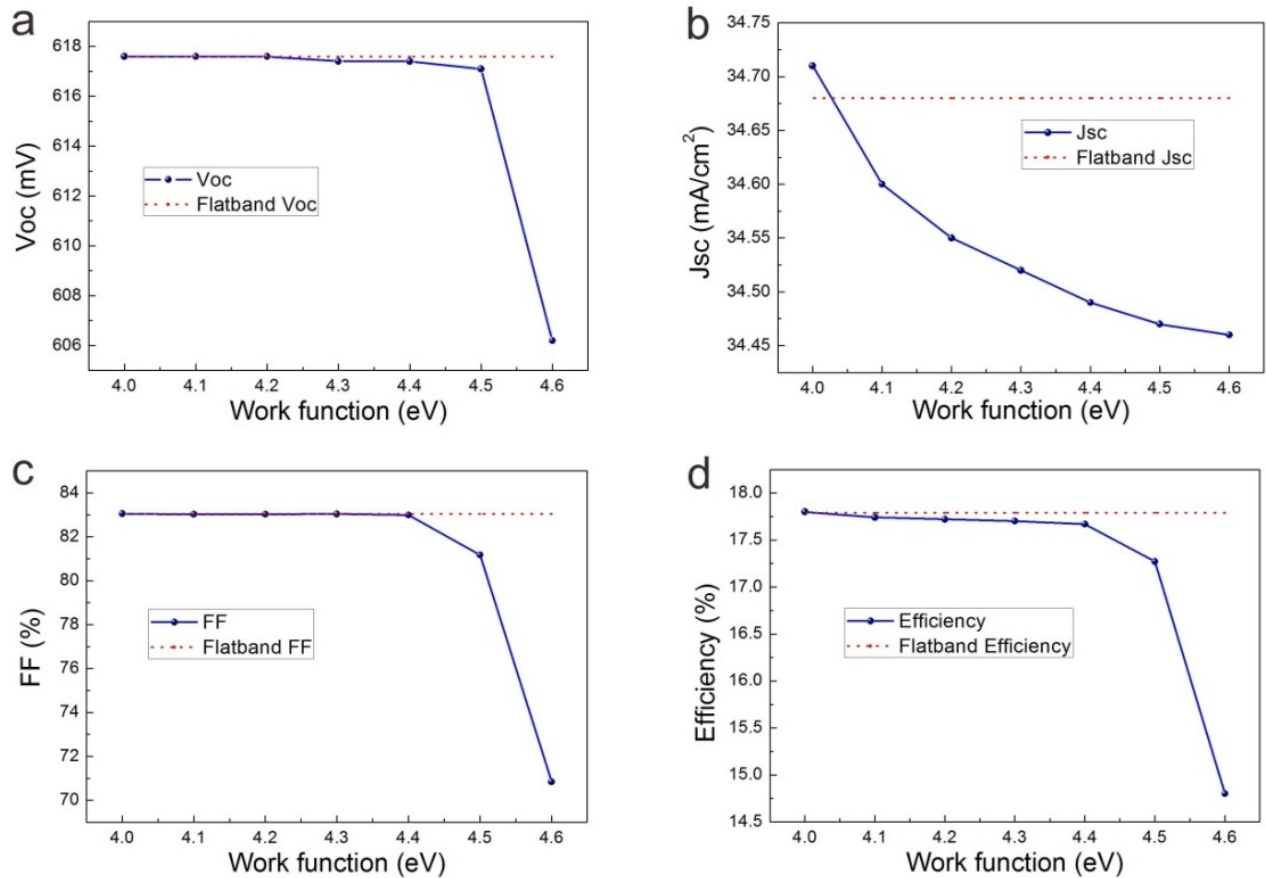

Fig.1 The variation trends of CdS/Si solar cell parameters caused by different TCO work function.

As shown in Fig.2a, the J-V curve is obviously affected when the TCO work function reaches 4.5 $\mathrm{eV}$, which means the formation of reverse electric field. When the work function is up to $4.6 \mathrm{eV}$, the reverse electric field is so strong that the $\mathrm{J}-\mathrm{V}$ curve is no longer a typical rectification curve. The energy band diagram shows that the TCO layer with work function at $4.6 \mathrm{eV}$ caused serious reversion (Fig. 2b). This result means that the reverse electric field is a detrimental factor when the TCO work function is too high.
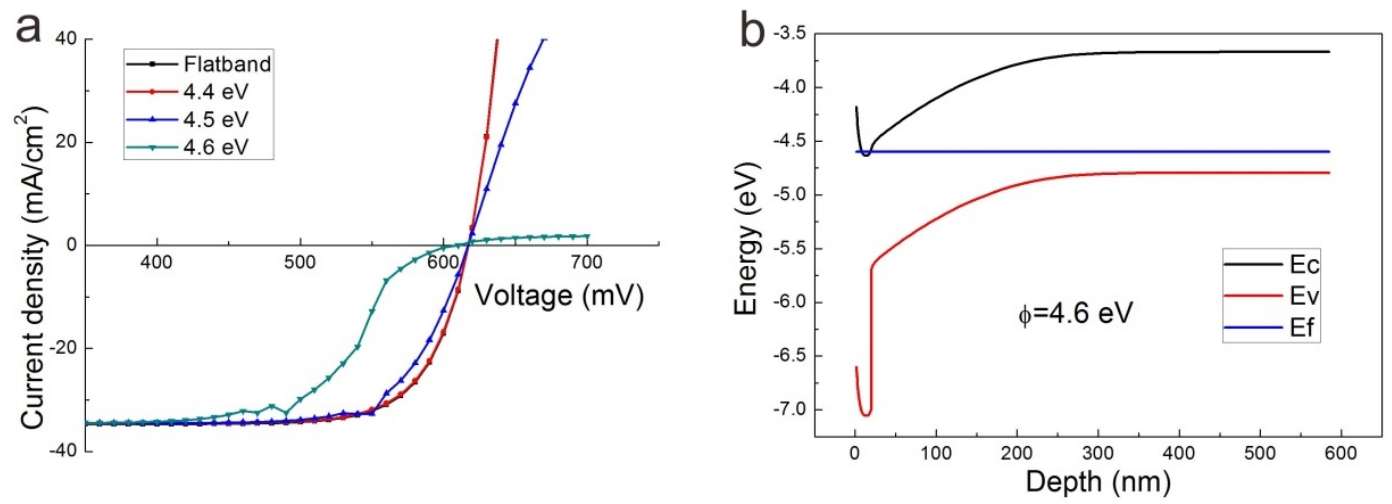

Fig. 2 The J-V curves and energy band of CdS/Si solar cell with different TCO work function.

Effects of the work function of BSF on parameters of CdS/Si solar cell were researched. The VOC, $\mathrm{FF}$ and PCE of CdS/Si solar cell increase when the work function of BSF becomes higher (Fig.3). The improvement is prominent when the work function of BSF is lower than $4.8 \mathrm{eV}$. But the parameters show little improvement when the work function further increases beyond $4.8 \mathrm{eV}$. JSC is not affected by the work function of BSF. 

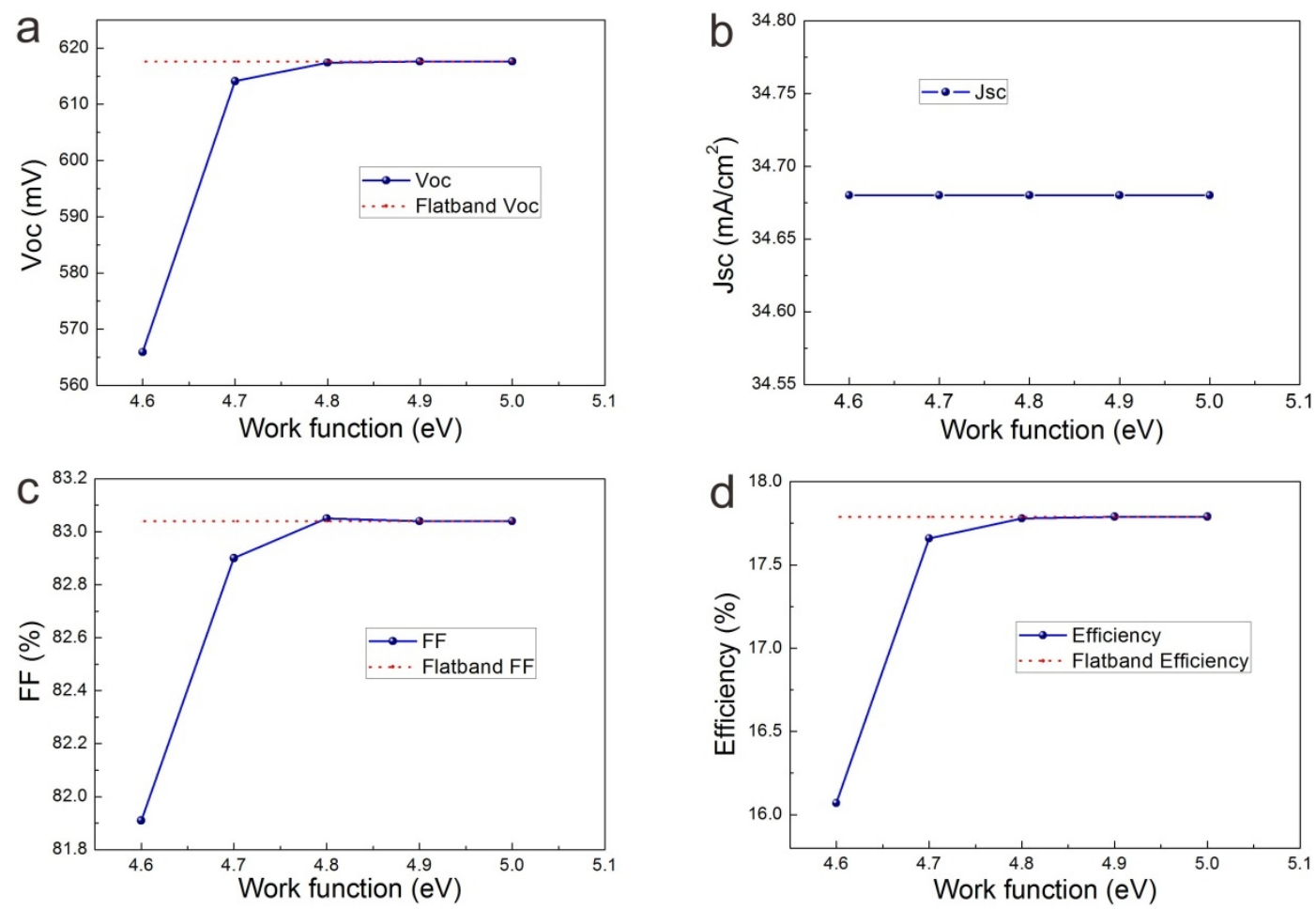

Fig.3 Effects of the work function of back contact on parameters of CdS/Si solar cell.

In contrast to the effect of TCO in the front surface, the BSF does not change the shape of the J-V curve which still shows the shape of a typical rectification curve (Fig.4). This means that although the parameters of the solar cell are obviously affected by the BSF, the J-V curves do not show the reverse electric field.

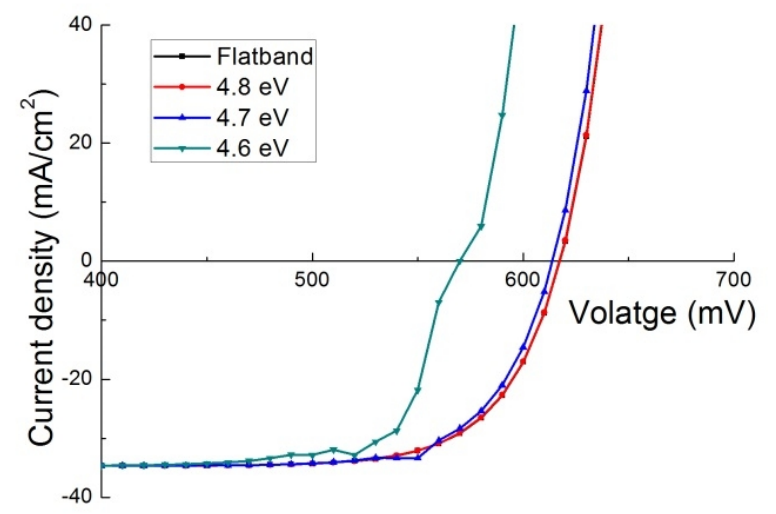

Fig.4 Effects of the work function of back contact on the J-V curves of CdS/Si solar cell.

The influence of thickness of CdS thin film on efficiency and other parameters of CdS/Si solar cell is also simulated (Fig.5). The values of VOC and JSC decrease gradually with thickness of CdS thin film increasing, while the FF stays stable as the CdS thickness varies. As a result, the PCE drops from $17.8 \%$ to $16.4 \%$ as the thickness of CdS thin film increases from $20 \mathrm{~nm}$ to $200 \mathrm{~nm}$. 

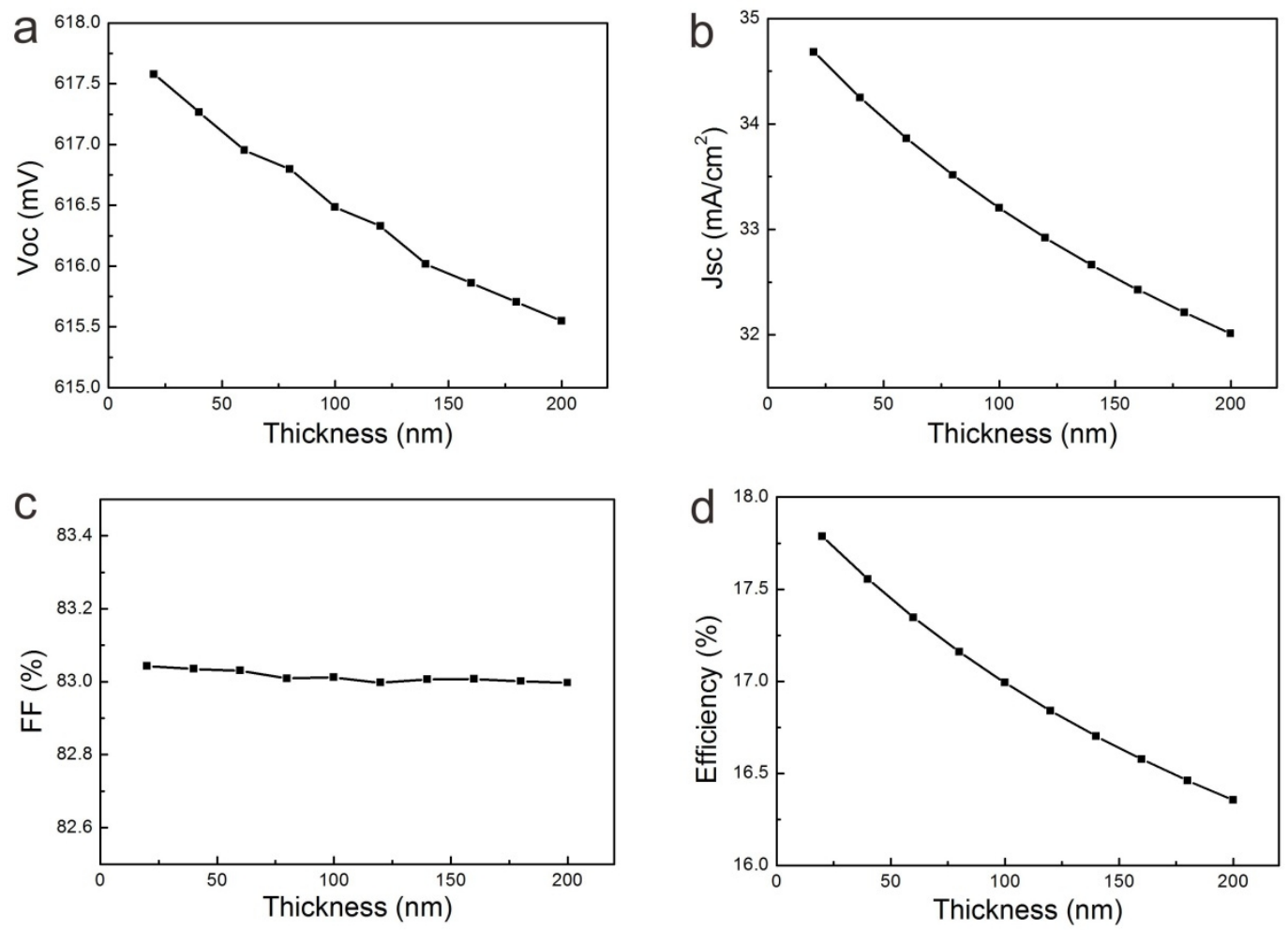

Fig.5 Influence of CdS thickness on the solar cell parameters

The external quantum efficiency (EQE) is affected as the thickness of CdS thin film increase (Fig.6(a)). The affected wavelength range is from $300 \mathrm{~nm}$ to $500 \mathrm{~nm}$, which indicates that the CdS thin film causes the parasitic optical absorption in short wavelength range. According to the simulation results, thickness of the CdS thin film should be as thin as possible. But in the fabrication, CdS thin films less than $10 \mathrm{~nm}$ is very likely to be discontinuous. The favorable thickness is among $15 \mathrm{~nm}$ to $20 \mathrm{~nm}$. The EQE results in Fig.6(b) show that thicker silicon substrates possess better absorption in visible and ultraviolet spectrum.
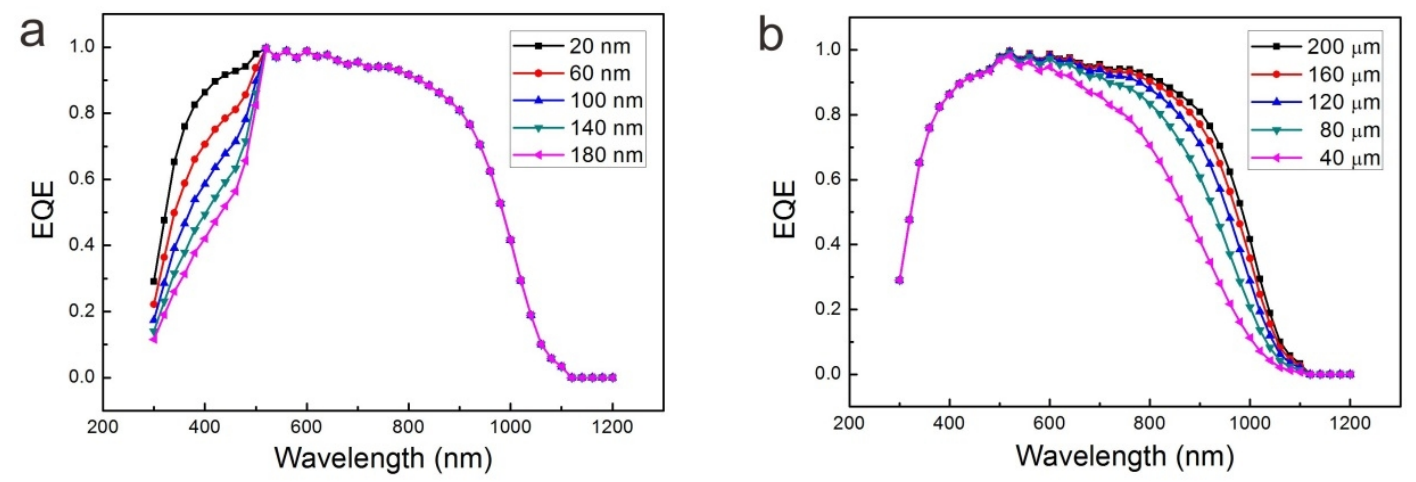

Fig.6 The EQE spectrum of CdS/Si solar cell with different CdS and Si thickness.

$\mathrm{CdS} / \mathrm{p}$-Si HJ solar cell at a size of $1 \mathrm{~cm} \times 1 \mathrm{~cm}$ was fabricated. CdS thin films were deposited on the front surface of the polished p-type monocrystalline silicon substrate by vacuum thermal evaporation. High work function material of $\mathrm{MoO}_{3}$ was deposited on the rear side of the solar cell to form the BSF. The thickness and performance of CdS thin film, TCO and BSF were optimized. In the end, under the condition of $25{ }^{\circ} \mathrm{C}$, AM 1.5 test, the PCE of $10.63 \%$ has been possessed for $\mathrm{Ag} / \mathrm{In}_{2} \mathrm{O}_{3} / \mathrm{n}-\mathrm{CdS} / \mathrm{p}-\mathrm{Si} / \mathrm{MoO}_{3} / \mathrm{Ag} \mathrm{HJ}$ solar cell with $40 \mathrm{~nm}$ thick $\mathrm{CdS}$ film. JSC, VOC, and FF are 
$28.75 \mathrm{~mA} \cdot \mathrm{cm}^{-2}, 543 \mathrm{mV}$, and $68.13 \%$, respectively. Comparing to the simulation results, the PCE of $\mathrm{CdS} / \mathrm{p}-\mathrm{Si} \mathrm{HJ}$ solar cell can be further increased. The difference between experimental and simulation results is mainly because the texture and passivation process is lacked during the fabrication. Both JSC and VOC are supposed to be improved with the presence of these steps. Also, the thin film preparation process still has room to be improved.
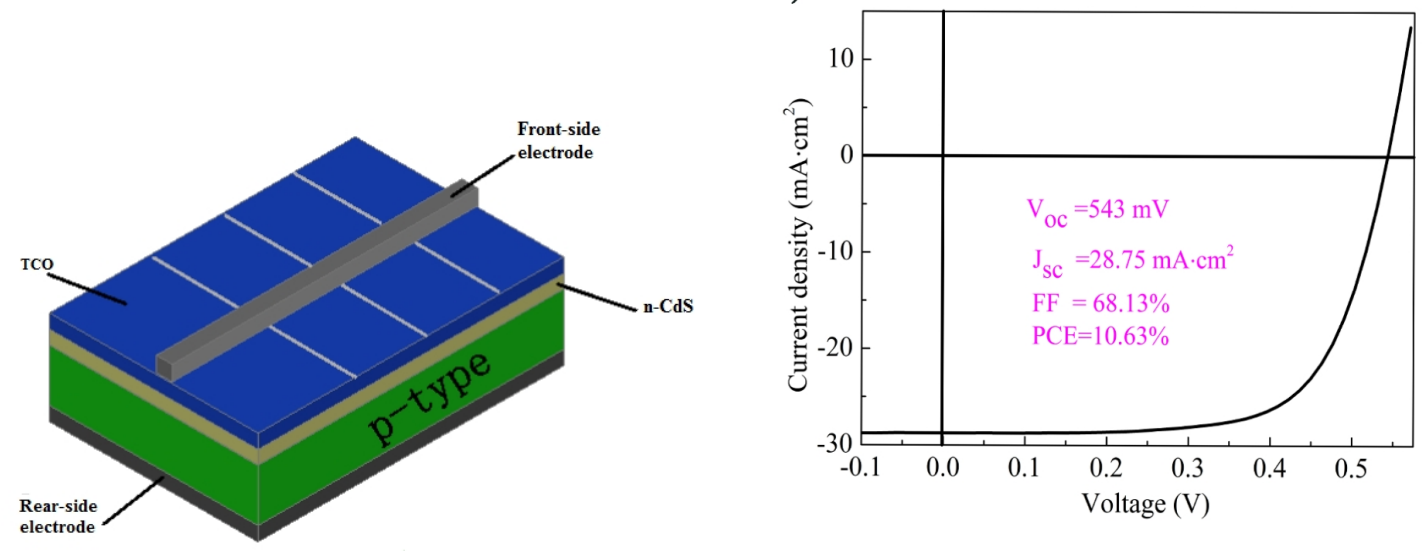

Fig.7 Schematic structure and J-V curve of CdS/Si solar cell

\section{Conclusions}

The CdS/Si HJ solar cells were analyzed by AFORS-HET. The work function of TCO and BSF were researched. Simulation results indicated that the TCO work function is supposed to be lower than $4.4 \mathrm{eV}$, and the work function of BSF is supposed to be higher than $4.8 \mathrm{eV}$. The energy band diagram indicates that the TCO layer causes reverse electric field in the HJ solar cell when the work function is higher than $4.5 \mathrm{eV}$. The CdS thin film is supposed to be lower than $20 \mathrm{~nm}$ to reduce the parasitic optical absorption in the short wavelength range. The CdS/Si HJ solar cell was fabricated and the efficiency was $10.63 \%$ in $1 \mathrm{~cm}^{2}$ area. Texturing and passivation is needed to further improve the efficiency of the CdS/Si solar cells.

\section{Acknowledgements}

This work is supported by the National High-tech R\&D Program of China [863 Program; Grant No. 2015AA050303 and 2015AA050608], the Guangdong-Hong Kong Technology Cooperation Funding Scheme [Grant No. 2014B050505010], Foshan science and technology innovation platform [Grant No. 2014AG10013 and 2014AG10020], Guangdong science and technology project [Grant No. 2014B040404002], Youth innovative project of Guangdong Education Department [Grant No. 2015KQNCX170].

\section{References}

[1] T Hayashi, T Nishikura, H Naomoto, H Ozawa, M Fukaya, Y Ema. p-Si/CdS heterojunction solar cells with BSF effect. Reports of the Faculty of Engineering, Shizuoka University (1990) 21-28.

[2] Toshiya Hayashi, Takehiro Nishikura, Kazuhiro Nishimura, Y Ema. p-Si/n-CdS heterojunction solar cells. Japanese Journal of Applied Physics 28 (1989) 1174.

[3] K Qiu, D Qiu, L Cai, S Li, W Wu, Z Liang, et al. Preparation of ZnS thin films and ZnS/p-Si heterojunction solar cells. Materials Letters 198 (2017) 23-26. 
[4] D. G. Baik, SM Cho. Application of sol-gel derived films for $\mathrm{ZnO} / \mathrm{n}-\mathrm{Si}$ junction solar cells. Thin Solid Films 354 (1999) 227.

[5] S Xu, Z Liang, H Shen. The preparation of AZO/a-Si/c-Si heterojunction structure on p-type silicon substrate for solar cell application. Materials Letters 137 (2014) 428-431.

[6] T Feng, AK Ghosh, C Fishman. Efficient electron-beam-deposited ITO/n-Si solar cells. Journal of Applied Physics 50 (1979) 4972.

[7] S Li, Z Yao, J Zhou, R Zhang, H Shen. Fabrication and characterization of WO 3 thin films on silicon surface by thermal evaporation. Materials Letters 195 (2017) 213-216.

[8] M Bivour, J Temmler, H Steinkemper, M Hermle. Molybdenum and tungsten oxide: High work function wide band gap contact materials for hole selective contacts of silicon solar cells. Solar Energy Materials and Solar Cells 142 (2015) 34-41.

[9] J Geissbühler, J Werner, S Martin de Nicolas, L Barraud, A Hessler-Wyser, M Despeisse, et al. $22.5 \%$ efficient silicon heterojunction solar cell with molybdenum oxide hole collector. Applied Physics Letters 107 (2015) 081601.

[10] J Bullock, M Hettick, J Geissbühler, AJ Ong, T Allen, Carolin M Sutter-Fella, et al. Efficient silicon solar cells with dopant-free asymmetric heterocontacts. Nature Energy 1 (2016) 15031.

[11] D Adachi, JL Hernández, K Yamamoto. Impact of carrier recombination on fill factor for large area heterojunction crystalline silicon solar cell with 25.1\% efficiency. Applied Physics Letters 107 (2015) 233506.

[12] K Masuko, M Shigematsu, T Hashiguchi, D Fujishima, M Kai, N Yoshimura, et al. Achievement of more than $25 \%$ conversion efficiency with crystalline silicon heterojunction solar cell. IEEE Journal of Photovoltaics 4 (2014) 1433-1435.

[13] AK Katiyar, S Mukherjee, M Zeeshan, SK Ray, AK Raychaudhuri. Enhancement of Efficiency of a Solar Cell Fabricated on Black Si Made by Inductively Coupled Plasma-Reactive Ion Etching Process: A Case Study of a n-CdS/p-Si Heterojunction Cell. ACS Appl Mater Interfaces 7 (2015) 23445-23453.

[14] O Vigil-Galán, M Courel, JA Andrade-Arvizu, Y Sánchez, M Espíndola-Rodríguez, E Saucedo, et al. Processing pathways of $\mathrm{Cu} 2 \mathrm{Zn}(\mathrm{SnGe}) \mathrm{Se} 4$ based solar cells: The role of CdS buffer layer. Materials Science in Semiconductor Processing 67 (2017) 14-19.

[15] A Froitzheim, R Stangl, L Elstner, M Kriegel, W Fuhs. AFORS-HET: A computer-program for the simulation of heterojunction solar cells to be distributed for public use. Tokyo: Wcpec-3 Organizing Committee; 2003.

[16] R Varache, C Leendertz, ME Gueunier-Farret, J Haschke, D Muñoz, L Korte. Investigation of selective junctions using a newly developed tunnel current model for solar cell applications. Solar Energy Materials and Solar Cells 141 (2015) 14-23. 